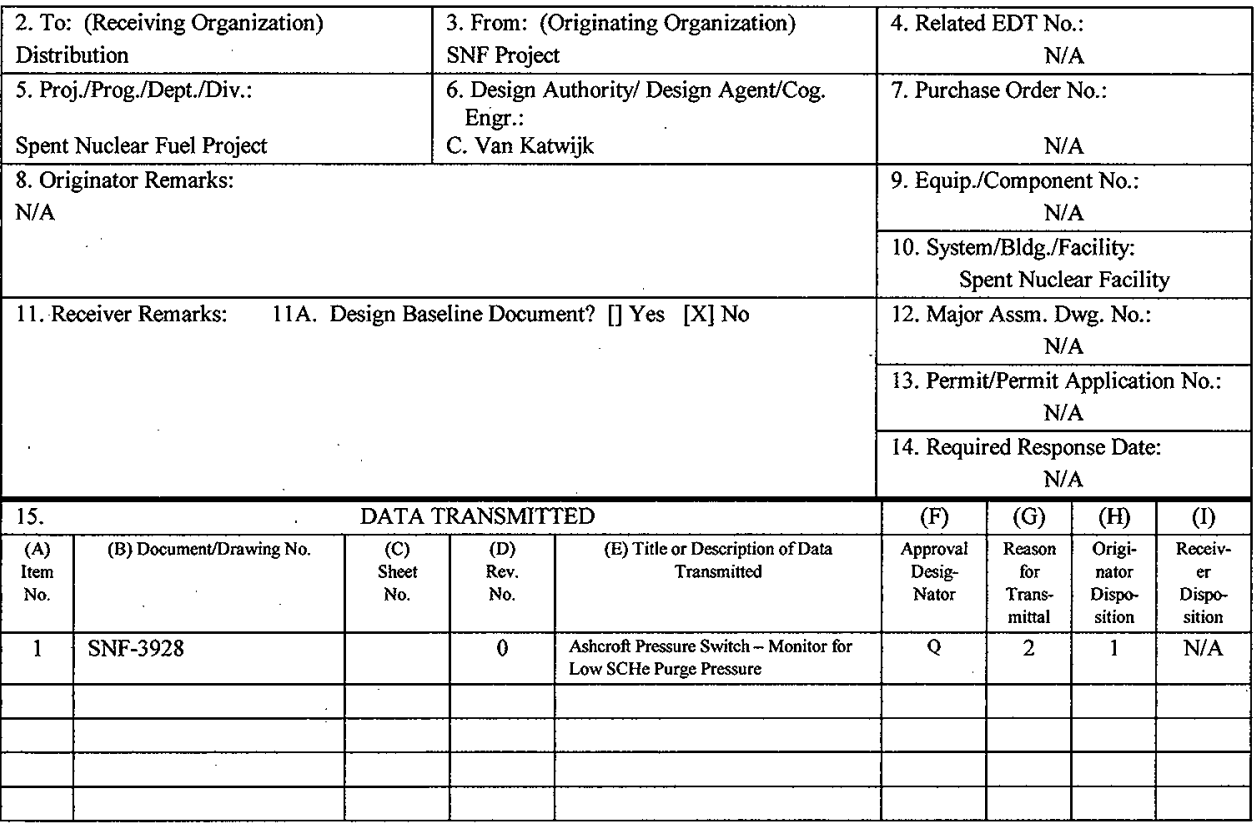

\begin{tabular}{|c|c|c|c|c|}
\hline Approval Designator (F) & & Reason for Transmittal (G) & \multicolumn{2}{|c|}{ Disposition (H) \& (I) } \\
\hline $\begin{array}{l}\text { E, S, Q, D or N/A } \\
\text { (see WHC-CM-3-5, } \\
\text { Sec.12.7) }\end{array}$ & $\begin{array}{l}\text { 1. Approval } \\
\text { 2. Release } \\
\text { 3. Information }\end{array}$ & $\begin{array}{l}\text { 4. Review } \\
\text { 5. Post-Review } \\
\text { 6. Dist. (Receipt Acknow. Required) }\end{array}$ & $\begin{array}{l}\text { 1. Approved } \\
\text { 2. Approved w/comment } \\
\text { 3. Disapproved w/comment }\end{array}$ & $\begin{array}{l}\text { 4. Reviewed no/comment } \\
\text { 5. Reviewed w/comment } \\
\text { 6. Receipt acknowledged }\end{array}$ \\
\hline
\end{tabular}
17. SIGNATURE/DISTRIBUTION (See Approval Designator for required signatures)

\begin{tabular}{|c|c|c|c|c|c|c|}
\hline $\begin{array}{l}\text { (G) } \\
\text { Rea- } \\
\text { son }\end{array}$ & $\begin{array}{l}\text { (H) } \\
\text { Disp. }\end{array}$ & $\begin{array}{lll}\text { (J) Name } & \text { (K) Signature (L) Date (M) MSIN }\end{array}$ & $\begin{array}{l}\text { (G) } \\
\text { Rea- } \\
\text { Son }\end{array}$ & $\begin{array}{l}\text { (H) } \\
\text { Disp. }\end{array}$ & (J) Name & (K) Signature (L) Date (M) MSIN \\
\hline 2 & I & Designated Engineer C. Van Katwijk & & & & \\
\hline 2 & 1 & Design Authority R. Whitehurst $R$ (un & & & & \\
\hline 2 & $\mathrm{t}$ & QA T.D. Hays Hath 36 d99 & & & & \\
\hline & & & & & & \\
\hline & & & & & & \\
\hline & & & & & & \\
\hline
\end{tabular}

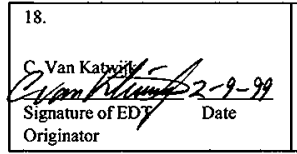

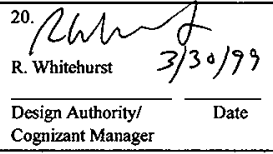

21. DOE APPROVAL (if required) Ctrl. No.

D] Approved

D] Approved w/comments

[] Disapproved w/comments 


\section{Ashcroft Pressure Switch - Monitor for Low SCHe Purge Pressure}

Carl Van Katwijk

Numatec Hanford Co, Richland, WA 99352

U.S. Department of Energy Contract DE-AC06"96RL13200

EDT/ECN: 626277

Org Code: $2 \mathrm{G} 300$

B\&R Code: $39 \mathrm{EW} 40400$
UC: 620

Charge Code: 105559/A000

Total Pages: 13

Key Words: Supply Bottle Pressure

Abstract: Ashcroft Pressure Switch - Monitor for Low SCHe Purge Pressure CGI-SNF-D-13-P5-031

TRAOEMARK DISCLAIMER. Reference herein to any specific commercial product, process, or service by trade name, trademark, manufacturer, or otherwise, does not necessarily constitute or imply its endorsement, recommendation, or favoring by the United States Government or any agency thereof or its contractors or subcontractors.

Printed in the United States of America. To obtain copies of this document, contact: Document Control Services, P.O. Box 950, Mailstop H6-08, Richland WA 99352, Phone (509) 372-2420; Fax (509) 376-4989.

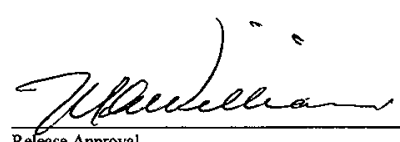

Release Approval

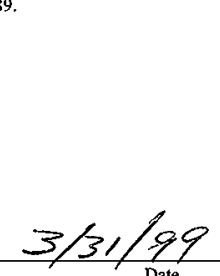

Date

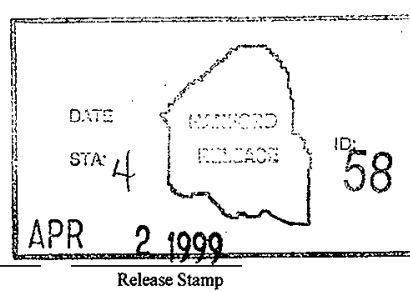




\begin{tabular}{|c|c|}
\hline Commercial Grade Item Upgrade Dedication Form & Rev. No. 0 \\
\hline ECN No. NA COINo. CGI-SNF-D-13-PS-031 & \multirow[t]{3}{*}{ Page 1 of 12} \\
\hline Title: ASHCROFT PRESSURE SWITCH-MONITOR FOR LOW SCHE & \\
\hline PURGE PRESSURE & \\
\hline
\end{tabular}

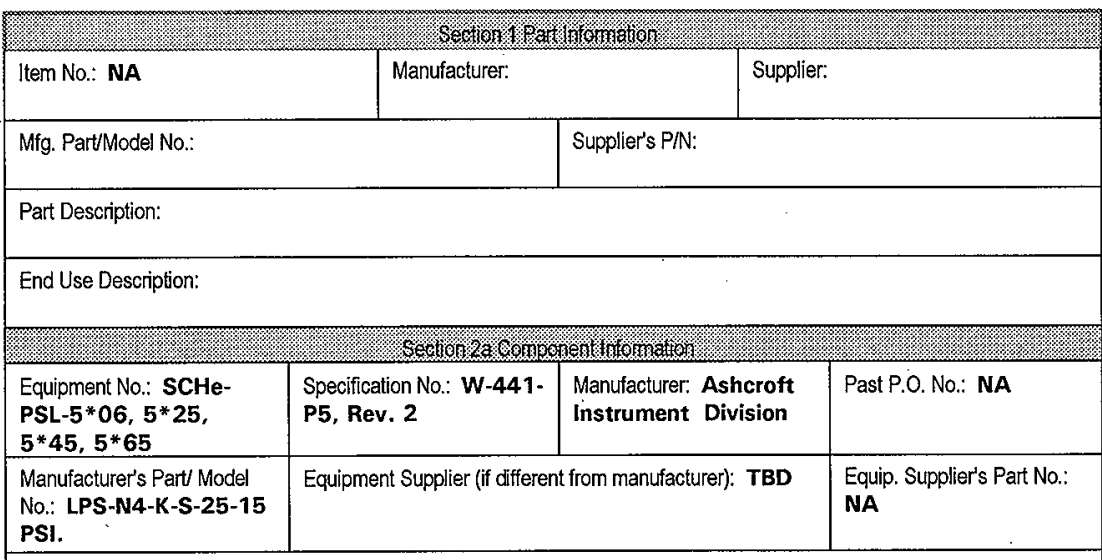

Component Description: These 0-15 psig pressure switches are located in the SCHe helium purge lines after PCV 5*23 (set for $15 \mathrm{psig}$ ) and before PCV 5*27 (set for $7 \mathrm{psig}$ ). The pressure switches monitor the pressure being maintained between the two PCVs and actuate on low pressure of 7.5 psig. This design is used for each of the SCHe supply lines (4). Electronic output signal is NONSAFETY (GS).

S.4.

1. Is the Item available from a catalog from a qualified NQA1 supplier (coordinate with project CGI interface Engineer or BTR)?

I ] YES (go to \#2 below)

$12 / 2 / 98$

[X] NO (go to procedure step 5.3.2, proceed to dedicate item.)

2. List of Candidate qualified suppliers $12 / 21 / 98$ company name and type contact name $12 / 22 / 28$ phone NA

3. Recommended Procurement Strategy (coordinate with project CG] interface Engineer or BTR):

NA

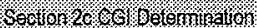

1. Question \#1: Is the Item subject to design or specification requirements that are unique to nuclear facilities or activities?

[ ] YES (the Item is not commercial grade)

$[\mathbf{X}] \quad$ NO (continue)

2. Question \#2: Is the Item used in applications other than nuclear facilities or activities?

[ ] $N O$ (the item is not commercial grade)

[X] YES (continue) 
Title: ASHCROFT PRESSURE SWITCH - MONITOR FOR LOW SCHe PURGE PRESSURE

3. Question \#3: Is the Item ordered from manufacturer/supplier on the basis or specifications set forth in the manufacturers catalog?

[ ] NO (the ltem is not commercial grade)

[X] YES (continue)

[X] All three criteria have been satisfied. The Item meets the definition of commercial grade.

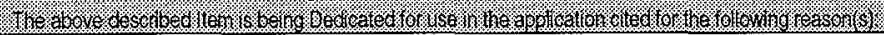

[X] .. Item is being purchased from a non ESL manufacturer supplier as commercial grade to be used in a Safety Class application.

[ ] Item is being purchased from a non ESL manufacturer supplier as commercial grade to be used in a Safety Significant application.

I ] Item was purchased from a non ESL manufacturer supplier as commercial grade to be used in a Safety Class application.

[ ] Item was purchased from a non ESL manufacturer supplier as commercial grade to be used in a Safety Significant application.

I I Other ('like-for-like', similar, substitution, replacement evaluation)

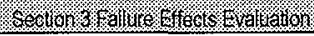

A. Part/Component Safety Function:

1. SCHe Pressure Boundary Integrity- Prevents helium leakage from the SCHe System.

2. Maintain pressure boundary after Seismic event.

3.

B. Part/Component Functional Mode

Safety Function \#1:

I ] Active - Mechanical or Electrical change of state is required to occur for the component to perform its safety function

[X] Passive - Change of state is not required for the component to perform its safety function Safety Function \#2:

[ ] Active - Mechanical or Electrical change of state is required to occur for the component to perform its safety function.

[X] Passive - Change of state is not required for the component to pefform its safety function Safely Function \#3:

[ ] Active-Mechanical or Electrical change of state is required to occur for the component to perform its safety function.

I ] Passive - Change of state is not required for the component to perform its safety function

C. Host Component Safety Function (if applicable):

1. NA

2.

3. 
Commercial Grade Item Upgrade Dedication Form

ECN No. NA CGINo.CGI-SNF-D-13-P5-031

Title: ASHCROFT PRESSURE SWITCH - MONITOR FOR LOW SCHe PURGE PRESSURE
Rev. No. 0

Page 3 of 12

D. Failure Mechanisms(s) and the effects on component or system safety function (see worksheet 1):

1. Fracture of the switch body or of the piping connection - helium leakage from the $\mathrm{SCHe}$ System.

2.

3.

4.

5 .

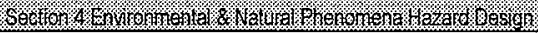

Environmental Qualification Required:

$$
\begin{aligned}
& \text { Yes [ ] } \\
& \text { No [ } \mathbf{X} \text { ] }
\end{aligned}
$$

Environmental Condition B

Natural Phenomena Hazard (NPH) Design Required:

$$
\begin{aligned}
& \text { Yes [ } \mathbf{X}] \\
& \text { No [ ] }
\end{aligned}
$$

HNF-PRO-97, Rev. 0

W-441-P5, Rev. 2

If yes: Environmental Qualification Requirements

Limiting Environmental Conditions:

Required Safety Functions:

Qualification Period:

If yes: NPH Design Requirements

Performance Category: PC-3

NPH Design Req'ts.: Seismic Condition B

Required Safety Functions: Pressure Boundary. Integrity

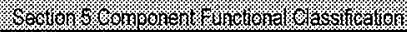

[ $\mathrm{X}$ ] Safety Class (SC)

[ IGeneral Service

[ ] Safety Significant (SS)

If part/component classification is different from host component/system, document basis.

National Codes/Standards:

IEEE-344, ISA-S5.1,-S5.4,-

S18.1,-S20
Safety Analysis Report (SAR):

HNF-SD-SNF-SAR-002, Rev.

4A
Drawings: H-1-82165, Rev. 2

HNF-SD-SNF-SEL-002, Rev. 4 GVOF-SSO-003 Ln $12 / 22 / 18$ $12 / 22 / 98$

Vendor Manuals/Manufacturer/Supplier Information: Ashcroft Instrument Division, L Series Switches, Bulletin SE-12

Other: 
Title: ASHCROFT PRESSURE SWITCH - MONITOR FOR LOW SCHe PURGE PRESSURE

4. Notes and Legend:

1. The pressure switch is not subject to degradation at ambient conditions of $40^{\circ} \mathrm{F}$ and $60 \% \mathrm{RH}$ or $115^{\circ} \mathrm{F}$ and 22\% RH and is suitable for Environmental Condition B application.

2. Maintain pressure boundary after Seismic event. W-441-P5, Rev. 2, Appendix I, page 1-2, provides a seismic testing plan for these components at a seismic spectra TBD. "Confinement" leakage acceptance criteria is $<10-4$ scc/sec.

3. Pressure test at $110 \%$ of system design pressure of $\mathbf{1 5 0}$ psig. Exposure to test pressure may seriously degrade the switch function. This test is considered to be a destructive test.

\section{Acceptance Method:}

1. Special Test and Inspection

$1_{1}$ IN for Inspection

$1, T$ for Test

2. Commercial Grade Survey

3. Source Verification

4. Vendor/tem History

\section{Approvals:}

Designated Engineer:

QA Engineer: $T 0$ daup $12 / 22 / 98$ 


\section{CHECKLIST 1}

ACCEPTANCE METHOD 1

SPECIAL TEST/MNSPECTION VERIFICATION

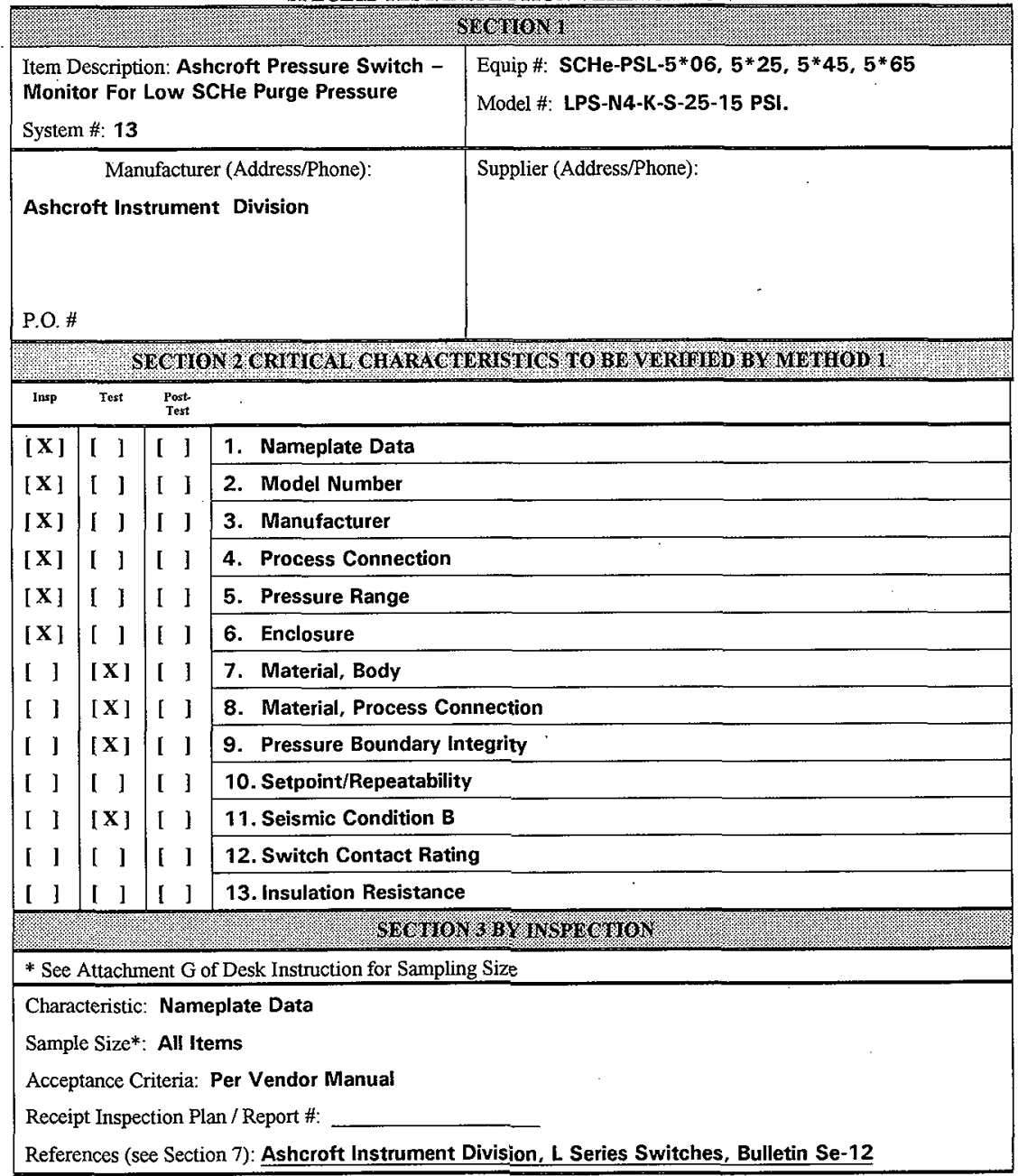


Title: ASHCROFT PRESSURE SWITCH-MONITOR FOR LOW SCHE PURGE PRESSURE

\section{Characteristic: Model Number}

Sample Size*: All Items

Acceptance Criteria: LPS-N4-K-S-25-15 PSI.

Receipt Inspection Plan/ Report \#:

References (see Section 7):

Characteristic: Manufacturer

Sample Size*: All Items

Acceptance Criteria: Ashcroft Instruments

Receipt Inspection Plan/Report \#:

References (see Section 7):

\section{Characteristic: Process Connection}

Sample Size*: All ltems

Acceptance Criteria: 1/4 Inch FNPT, Bottom Mounted

Receipt Inspection Plan / Report \#:

References (see Section 7):

Characteristic: Pressure Range

Sample Size*: All Items

Acceptance Criteria: 0-15 PSIG

Receipt Inspection Plan / Report \#:

References (see Section 7):

Characteristic: Enclosure

Sample Size*: All Items

Acceptance Criteria: NEMA 4,4X

Receipt Inspection Plan / Report \#:

References (see Section 7):

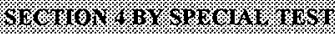

* See Attachment $G$ of Desk Instruction for Sampling Size

Test To Be Performed by:

[ ] Purchaser

I ] Supplier/Manufacturer**

Number of Items to be Tested:

[ ] Other

Characteristic for Test: Material, Body

Acceptance Criteria: Stainless Steel

Sample Size*: Normal Sampling Size

Actual Test Value:

Test Plan and Report \#: References (see Section 7): 


ECN No. NA CGI No.CGI-SNF-D-13-P5-031
Title: $\frac{\text { ASHCROFT PRESSURE SWITCH - MONITOR FOR LOW SCHe }}{\text { PURGE PRESSURE }}$
PURE

Characteristic for Test: Material, Process Connection

Acceptance Criteria: Stainless Steel

Sample Size*: Normal Sampling Size

Actual Test Value:

Test Plan and Report \#: References (see Section 7):

Characteristic for Test: Pressure Boundary Integrity

Acceptance Criteria: No Leakage at Test Pressure of 165 Psig

Sample Size*: Destructively Test Only One Item

Actual Test Value:

Test Plan and Report \#:

References (see Section 7)

Characteristic for Test: Seismic Condition B

Acceptance Criteria: Maintain Pressure Boundary After Seismic Event. "Confinement" leakage acceptance criteria is $<10-4 \mathrm{scc} / \mathrm{sec}$.

Sample Size*: Normal Sampling Size

Actual Test Value:

Test Plan and Report \#: References (see Section 7):

Characteristic for Test:

Acceptance Criteria:

Sample Size*:

Actual Test Value:

Test Plan and Report \#: References (see Section 7):

Characteristic for Test:

Acceptance Criteria:

Sample Size*:

Actual Test Value:

Test Plan and Report \#: References (see Section 7):

Characteristic for Test:

Acceptance Criteria:

Sample Size*:

Actual Test Value:

Test Plan and Report \#:

References (see Section 7)

**If Supplier/Manufacturer or Other, Refer to CGI Checklist-2 for Support Information 


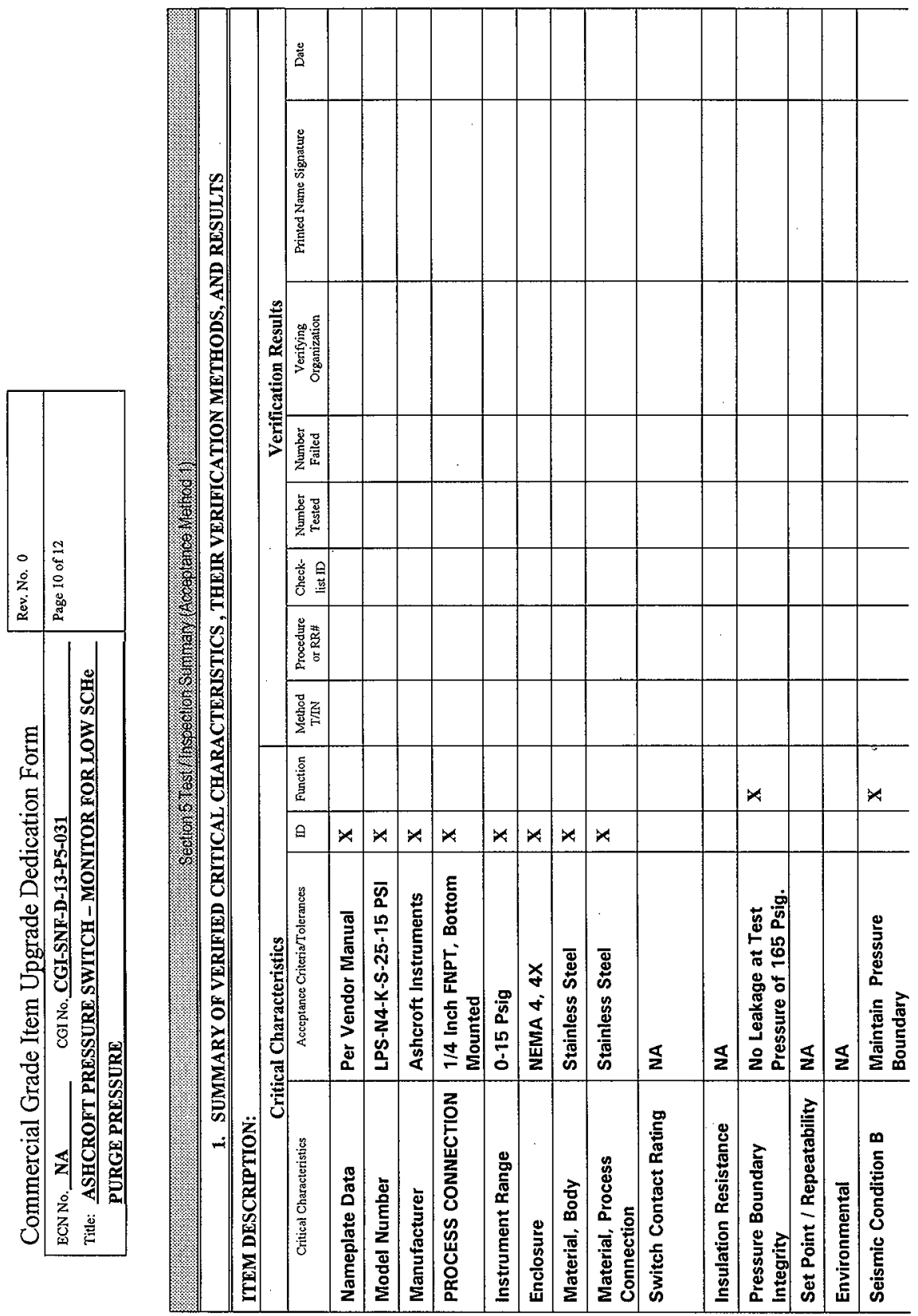



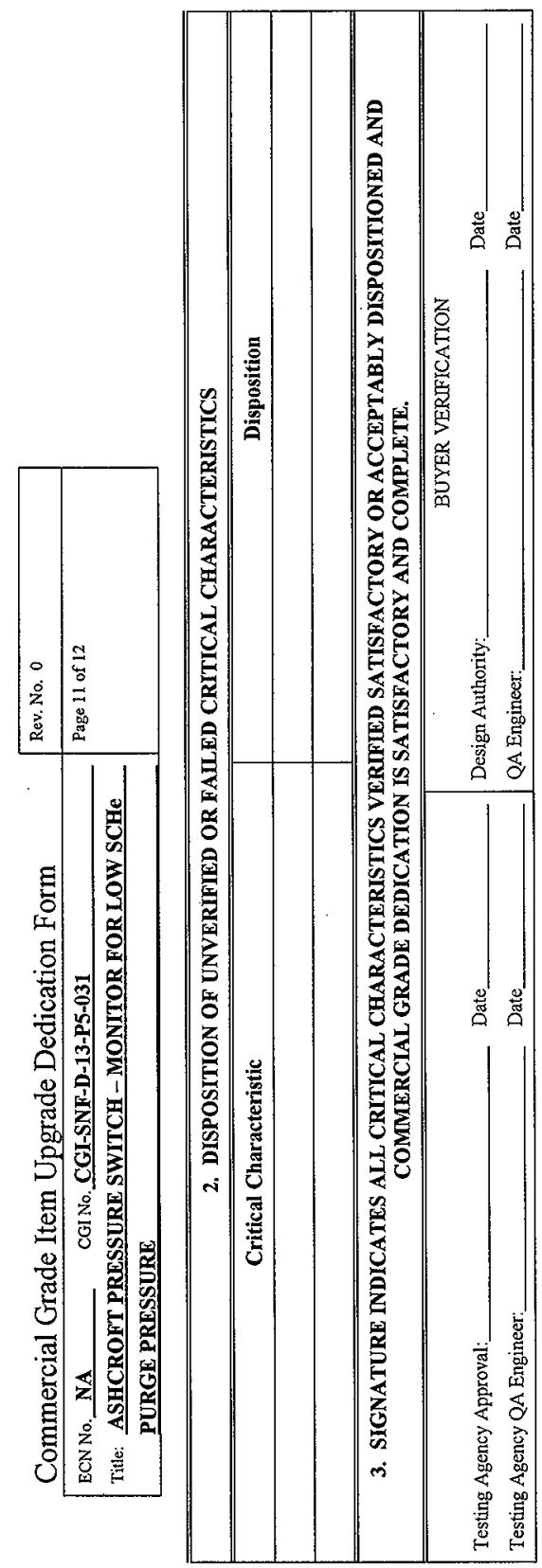


\section{ECN No. NA CGI No. CGI-SNE-D-13-P5-031 \\ Title: ASHCROFT PRESSURE SWITCH - MONITOR FOR LOW SCHe PURGE PRESSURE}

\begin{tabular}{|c|c|}
\hline \multicolumn{2}{|l|}{ Name } \\
\hline Design Authority & $(\quad)$ \\
\hline QA & ( \\
\hline $\mathrm{QC}$ & $(\quad)$ \\
\hline Cog - Engineer & ( \\
\hline CGI Engineer & $(\quad)$ \\
\hline Procurement Engineer & ( \\
\hline \multicolumn{2}{|c|}{ 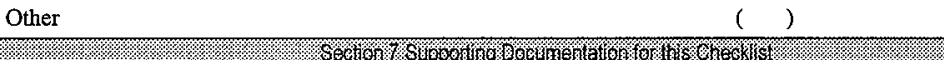 } \\
\hline 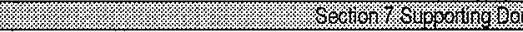 & 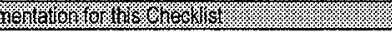 \\
\hline \multicolumn{2}{|c|}{\begin{tabular}{|l|l|} 
Initial Procurement Documents & For Critical Characteristics \\
\end{tabular}} \\
\hline \multicolumn{2}{|l|}{ [ ] Drawings: } \\
\hline \multicolumn{2}{|l|}{ [ ] Manuals (specify type \& number): } \\
\hline \multicolumn{2}{|l|}{ [ ] Design Calculations } \\
\hline \multicolumn{2}{|l|}{ [ ] Installation Instructions } \\
\hline \multicolumn{2}{|l|}{ I ] Operation Instructions } \\
\hline \multicolumn{2}{|l|}{ [ ] Calibration Instructions } \\
\hline \multicolumn{2}{|l|}{ [ ] Manufacturer's Recommended Spare Parts List } \\
\hline \multicolumn{2}{|l|}{ [ ] Other: } \\
\hline \multicolumn{2}{|l|}{ Procurement Documents } \\
\hline \multicolumn{2}{|l|}{ [ ] Certificate of Conformance/Compliance } \\
\hline \multicolumn{2}{|l|}{ [ ] Seismic Qualification Certificate } \\
\hline \multicolumn{2}{|l|}{ [ ] Environmental Qualification Certificate } \\
\hline \multicolumn{2}{|l|}{ [ ] Test Report (s): } \\
\hline \multicolumn{2}{|l|}{ [ ] Inspection Report (s): } \\
\hline \multicolumn{2}{|l|}{ I I CMTRs for ASME Pressure Retaining Materials } \\
\hline \multicolumn{2}{|l|}{ [ ] Valve Seat Leakage Report } \\
\hline \multicolumn{2}{|l|}{ I ] Weld Records } \\
\hline \multicolumn{2}{|l|}{ [ ] Material Traceability Record } \\
\hline [ ] Other: & \\
\hline
\end{tabular}

